\title{
IDENTIFIKASI ISOLAT FUNGI ENDOFIT LBKURCC43 BERDASAR SEKUENS ITS rDNA DARI UMBI TANAMAN DAHLIA (DAHLIA VARIABILIS)
}

\author{
Sefni Hendris ${ }^{1}$, Titania T. Nugroho ${ }^{2}$, Saryono ${ }^{2}$ \\ ${ }^{1}$ Mahasiswa Program Studi S2 Kimia \\ ${ }^{2}$ Bidang Biokimia Jurusan Kimia FMIPA Universitas Riau \\ Kampus Binawidya Pekanbaru, 28293, Indonesia \\ sefnihendris@yahoo.co.id \\ saryono_ur@yahoo.com
}

\begin{abstract}
ABSTRAK
Fungi LBKURCC43 merupakan fungi endofit yang diisolasi dari umbi tanaman dahlia berbunga ungu (Dahlia variabilis) di Padang Panjang, Sumatera Barat. Identifikasi secara morfologi isolat tersebut telah dilakukan dan hanya mengidentifikasi pada tingkat genus. Identifikasi secara molekuler dengan menggunakan DNA adalah identifikasi spesies yang lebih tepat digunakan. Sebelum dilakukan analisis filogenetik secara molekuler berdasarkan sekuens DNA ribosomal pada daerah ITS-1 dan ITS-2, dilakukan ekstraksi DNA dan amplikasi PCR ITS rDNA yang baik untuk sekuensing. DNA kromosomal diisolasi menggunakan kit Wizard Genomic Purification ex Promega Co (Madison, USA) dari sel miselia berumur tiga hari. Hasil penelitian menunjukkan bahwa DNA berhasil diisolasi dari miselia yang berumur tiga hari sebelum terbentuk spora dan jumlah yang cukup tinggi untuk PCR. DNA kromosomal fungi LBKURCC43 memiliki BM (berat molekul) 10.294 pb. ITS rDNA berhasil diamplifikasi dengan PCR menggunakan pasangan primer ITS5 dan ITS4, suhu annealing untuk $44^{\circ} \mathrm{C}$ dan menghasilkan produk PCR dengan berat molekul $455 \mathrm{pb}$. Hasil analisis filogenetik daerah ITS-1, ITS-2 dan 5,8S rDNA dari genom fungi LBKURCC43 menunjukkan bahwa spesies dari fungi LBKURCC43 adalah Hanseniaspora uvarum dengan kemiripan identitas mencapai $97 \%$.
\end{abstract}

Kata Kunci: Endofit, PCR, ITS, rDNA, Hanseniaspora uvarum

\section{PENDAHULUAN}

Mikrob endofit adalah mikrob yang seluruh atau sebagian hidupnya berada di dalam jaringan hidup tanaman inang tanpa menimbulkan gejala yang merugikan bagi tanaman inang itu sendiri. Mikrob seperti kapang, khamir dan bakteri dapat berasosiasi dengan tanaman membantu metabolisme tanaman inang dan menghasilkan metabolit sekunder yang berpotensial (Kumala et al., 2006). Beberapa penelitian juga menunjukkan bahwa endofit memberikan keuntungan bagi tanaman inangnya, seperti melindungi dari serangan serangga, patogen dan hewan herbivora (Ding et al., 2011).

Tanaman dahlia (Dahlia variabilis) merupakan bunga berumbi yang digunakan sebagai tanaman hias atau bunga potong. Tanaman dahlia dapat digunakan sebagai obat- obatan manusia karena memiliki potensi dalam menghasilkan senyawa bioaktif. Ekstrak umbi dahlia diketahui mengandung senyawa fenolik, flavonoid, dan saponin yang memiliki aktivitas antimikroba Escherichia coli, Bacillus subtilis, dan Staphylococcus aureus (Suryadi, 2007).

Pada penelitian sebelumnya, telah diisolasi jamur endofit dari umbi dahlia berbunga ungu yang berasal dari Padang Panjang, Sumatera Barat diidentifikasikan secara morfologi sebagai Sporothrix sp. LBKURCC43 (Lorenita, 2013). Subjek berhasil diisolasi dan ditentukan genusnya secara makroskopis dan mikroskopis. Untuk skirining aktivitas antimikroba dan uji fitokimia dari Fungi LBKURCC43 menunjukkan aktivitas antimikroba dengan media produksi Huang et al. (2007). LBKURCC 43 menunjukkan adanya aktivitas antibakteri 
terhadap Escherichia coli dan Staphlococcus aureus setelah di inkubasi hingga hari ke-20 dan hasil uji fitokimia menunjukkan bahwa Fungi LBKURCC43 positif mengandung saponin (Fitriyah, 2013). Senyawa saponin memiliki peran alami dalam tanaman sebagai pelindung terhadap patogen dan hama (Turk, 2005).

Identifikasi fungi LBKURCC43 telah dilakukan secara morfologi berupa warna, diameter koloni, dan pigmen koloni. Hal ini lebih tepat untuk identifikasi hingga tingkat genus, dan belum dapat memberikan kepastian untuk identifikasi pada tingkat spesies. Identifikasi morfologi tersebut belum memberikan kepastian spesies maupun hubungan kekerabatan dengan spesies. Oleh karena itu perlu dilakukan suatu cara identifikasi yang lebih tepat berdasarkan sekuens DNA ribosomal (rDNA) pada daerah ITS (Internal Transcribed Spacer) (Hutapea, 2007). Secara ekstensif metode ini digunakan untuk mengetahui basa-basa nukleotida informasi total genom dalam suatu sel atau organisme (Muslim, 2003). Daerah ITS tersebut harus diamplikasi terlebih dahulu sebelum dilakukan sekuens ITS rDNA untuk identifikasi spesies Fungi. Ada dua daerah ITS rDNA yang bersifat diagnostik yang dapat digunakan untuk identifikasi spesies fungi, karena memiliki keragaman tinggi. Kedua daerah tersebut adalah ITS-1 dan ITS-2 (Druzhinina dkk., 2005). Verifikasi hasil pemeriksaan morfologi dan identifikasi fungi di tingkat spesies, dapat dilakukan dengan analisis filogenetika menggunakan sekuens ITS-1 dan ITS-2 gen DNA ribosomal (rDNA) lainnya. Dalam kebanyakan kasus, data sekuens dan hubungan filogenetika memungkinkan identifikasi pada tingkat spesies (Wiese dkk. 2011).

Isolasi DNA merupakan tahap pertama dari berbagai teknologi analisis DNA. Isolasi DNA diperlukan untuk mendapatkan DNA murni yang akan digunakan untuk amplifikasi Polimerase Chain Reaction (PCR). Amplifikasi DNA menggunakan PCR di daerah ITS rDNA dari templat DNA kromosomal diperlukan untuk memudahkan penentuan sekuens DNA ITS tersebut. Hal ini disebabkan bila tidak dilakukan amplifikasi, maka sekuens DNA kromosomal lain akan mengganggu penentuan sekuens ITS rDNA. Daerah ITS rDNA hanya mencakup $0,0002 \%$ dari keseluruhan kromosom, jadi bila tidak dilakukan amplifikasi daerah DNA yang akan di sekuens, gangguan sekuens lain terlalu besar.
Penelitian ini akan dilakukan suatu identifikasi yang tepat berdasarkan sekuens DNA ribosomal pada daerah ITS (Internal Transcribed Spacer) yang dilengkapi dengan analisis filogenetik mengenai Fungi tersebut. Wiese dkk (2011) mengatakan bahwa untuk mengidentifikasi spesies Fungi dapat digunakan sekuens daerah ITS-1 dan ITS-2 rDNA-nya.

\section{METODOLOGI PENELITIAN}

Kultur fungi LBKURCC41 dari umbi dahlia berbunga kuning koleksi Laboratorium Biokimia-FMIPA, Universitas Riau yang diisolasi dari umbi Dahlia variabilis yang diambil di Padang Luar, Sumatera Barat. Media SDA (Sabouraud 4\% dextro agar) keluaran Merck. Litikase keluaran SIGMA-Aldrich Chemical Co.St. Louis, USA(Nomor catalog L2524), larutan Ethidium Bromide keluaran Bio$\mathrm{rad}, 10 \mathrm{mg} / \mathrm{ml}$ (Nomor catalog 161-0433), Kit Wizard genomic Purification keluaran Promega, Madison, Wi, USA (Nomor catalog A-1120), 1 $\mathrm{Kb}$ DNA Ladder keluaran Promega, Madison, WI, USA (Nomor catalog G-5711), sebagai standar DNA. Go Taq ${ }^{\text {TM }}$ PCR Core system I keluaran Promega,USA (No. Kat. M7660), untuk reaksi amplifikasi DNA. Primer-primer ITS1, ITS2, ITS3, ITS4, dan ITS5 produksi PT. Sentra Biosains Dinamika, Jakarta sesuai dengan sekuens yang dipublikasi oleh White dkk., (1990), Buffer tris-base, EDTA, $\mathrm{CH}_{3} \mathrm{COOH}$, $\mathrm{HCL}, \mathrm{NaOH}$, bromphenol blue, dan Gel Agarosa.

Kultur fungi LBKURCC 41 dari umbi dahlia berbunga kuning, diremajakan pada media pertumbuhan. Isolasi DNA dilakukan dengan metode kit Wizard genomic yang menggunakan enzim litikase dan bahan-bahan dari Kit Wizard genomic DNA purification (Promega). Hasil ekstrasi DNA kemudian dielektroforesis dengan menggunakan gel agarosa $0.8 \%$ dan pemisahan DNA tersebut difoto dengan menggunakan camera digital Sony Cyber-shot DSC- W610 14,1 megapixels. DNA yang berhasil diisolasi ditentukan berdasarkan pita DNA yang terlihat dan akan dijadikan templat pada amplifikasi dengan metode Polymerase Chain Reaction (PCR). Untuk menentukan sekuens daerah ITS-1 dan ITS-2 digunakan primer ITS-4 dan ITS- 5, maka akan dicoba pasangan primer ITS lain yang cocok. 
Kecocokan pasangan primer-primer ini dapat dilihat berdasarkan pita DNA yang terlihat pada UV transimulator setelah dielektroforosis dengan gel agarosa $1.2 \%$. Fragmen PCR ini kemudian ditentukan urutan DNA-nya berdasarkan proses sekuensing dengan metode Sanger

\section{HASIL DAN PEMBAHASAN}

\section{a. Isolasi DNA}

Miselium yang terbaik untuk isolasi DNA LBKURCC40 adalah berumur 3 hari (Gambar 1). Isolasi DNA dilakukan menggunakan metode kit Wizard ex Promega Corp. adanya pita DNA tunggal yang terlihat dengan bantuan sinar UV pada gel elektroforesis menunjukkan bahwa adanya pita DNA. Untuk miselium LBKURCC41 waktu yang terbaik untuk dilakukan isolasi DNA adalah berumur 3 hari. Adanya pita berflouresensi dengan ukuran kisaran 10.000 sampai $12.000 \mathrm{pb}$ menandakan DNA LBKURCC41 telah berhasil diisolasi (Gambar 2).

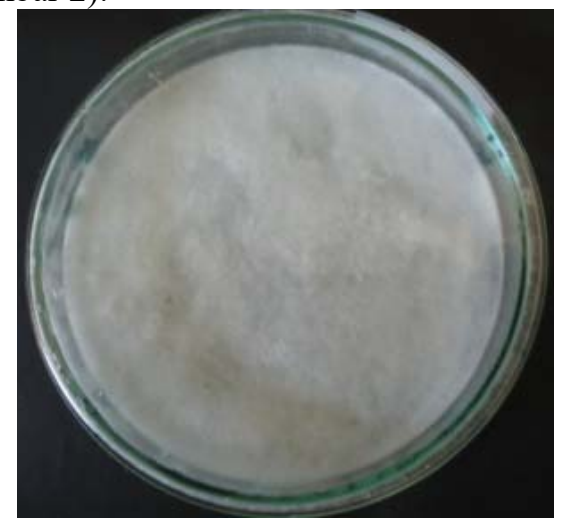

Gambar. 1 Morfologi koloni isolat fungi endofit LBKURCC43 berumur 3 hari sebelum isolasi DNA.

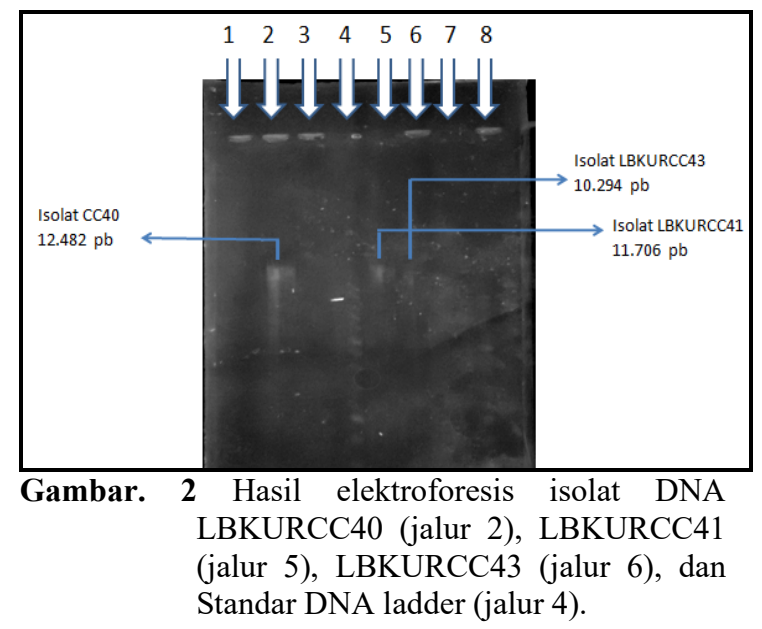

\section{b. Amplifikasi PCR}

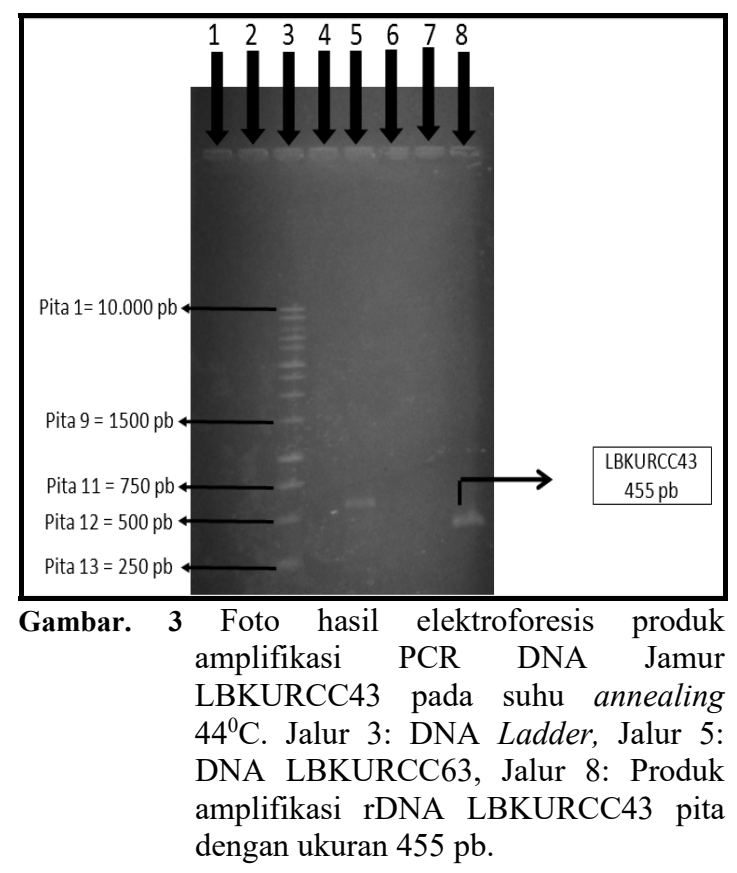

Gambar 3 menunjukkan hasil elektroforesis amplifikasi PCR dengan kombinasi ITS4 dan ITS 5 diperoleh berat molekul berdasarkan persamaan regresi linier diatas, Hasil amplifikasi PCR dielektroforesisi pada gel agarosa $1.2 \%$ dan diwarnai dengan Etidium Bromida agar berflouresensi di bawah sinar UV, hasil yang tampak pada gambar 2 (LBKURCC43). Sama halnya dengan penentuan berat molekul pada isolat, hasil amplifikasi PCR diperoleh dengan mengukur jarak migrasi standar. Persamaan regresi yang diperoleh untuk LBKURCC43 adalah $\mathrm{y}=-0,0351 \mathrm{x}+4,762$. Persamaan regresi ini yang akan digunakan dalam menentukan berat molekul sampel hasil PCR maka untuk berat molekul Untuk LBKURCC43 dengan jarak migrasi $59 \mathrm{~mm}$ adalah $455 \mathrm{pb}$.

\section{c. Pengurutan DNA Produk Amplifikasi PCR}

Identifikasi secara molekuler berdasarkan urutan DNA ribosomal pada daerah ITS (Internal Transcribe Spacer) merupakan salah satu usaha untuk mengidentifikasi dan membuka informasi genetik suatu Fungi. Setelah produk amplikasi PCR diperoleh, kemudian produk tersebut ditentukan urutan DNA-nya yaitu pada daerah ITS1 dan ITS2 rDNA menggunakan gabungan primer ITS4 dan ITS5. Penentuan urutan DNA Fungi LBKURCC41 
dilakukan dengan mengunakan jasa sekuensing pada Lembaga Sekuensing Eijkman di Jakarta. Data yang diperoleh diverifikasi secara manual mengacu pada spektrogram, dengan membaca puncak-puncak.

Spektrogram hasil sekuensing memiliki 4 warna yaitu merah untuk Timin (T), warna biru untuk Citosin (C), warna hitam untuk Guanin $(G)$, dan warna hijau untuk Adenin (Lampiran 2). Setelah dilakukan pembacaan secara visual, kemudian hasil pengurutan dicocokkan secara manual dalam arah yang berlawanan dari kedua rantai DNA dengan tujuan verifikasi.

Gambar. 4 Urutan DNA LBKURCC43 hasil verifikasi pada program Bioedit
Verifikasi untuk daerah ITS-1 rDNA dengan pasangan primer ITS5 dan ITS2, maka ITS5 menjadi forward dan ITS2 menjadi reverse. Pada daerah ITS-2 rDNA, ITS3 menjadi forward dan ITS4 menjadi reverse. Proses ini dilakukan pada ketiga sampel LBKURCC40, LBKURCC41, dan LBKURCC43. Untuk mempermudah proses verivikasi dilakukan dengan penggunakan perangkat lunak (software) Bioedit. Data-data urutan DNA hasil pairwaise aligment pada program Bioedit dapat dilihat masing-masing pada gambar 4 .

> Urutan DNA LBKURCC-43 (5'- $\mathbf{- 3}$ ')
TGGAAGTAAAAGTCGTAACAAGGTCTCTCATCGTAGGTGAACCCTGCGGAAGGATCATTAACATAATATTCTTA
CACAGCTGTTTTTTACAACAAAACAAATCTATCTAAAAACAATTCTTTACAAGAAATTCTTAAAACTTTCAAC
AACGGATCTCTTGGTTCTCGCATCGATGAAGAACGCAGCGAAATGCGATACGTAATACGAATCGCAGCTCTCG
GAATCATCGAATCTTTGAACGCACATTGCACCATTGGGTATTCCCAATGGTATGCTTGTTTGAGCGAATACTTCC
CTAATCCTCACGGATTGTATTGTGTTTGCACGAAAATAATGACGACAGTACTCTACAAAACGGTACCGTCAGTA
CACTCATTTTTTTCCTCAAATCAAGTAGGACTACCCGCTGAACTTAAGCATATCAATAAGCGGAGGAATCTAA
GGTTGACCTCGGATCAGGTAGGAATACCCGCTGAACTTAAGCATATCAATAAGCGGAGGA

d. Analisis filogenetik pada sekuens daerah ITS-1 dan ITS-2 rDNA

Analisis sekuens daerah ITS-1 5,8S rDNA dan

ITS-2 LBKURCC40 dibandingkan terhadap daerah yang sama yang dimiliki 7 galur Saccharomyces, dan kerabat dekat yang diakses pada data GenBank NCBI (tabel 1), pada tanggal 29 Agustus 2014. Hasil penyejajaran dengan program Clustal $\mathrm{X}$ versi 2.09, generasi pohon N.J Bootstrapping ditampilkan software TreeView sebagai pohon dendogram dan filogram tak berakar yang ditunjukkan di Gambar 4 dan Gambar 5.

Tabel. 1 Nama spesies, kode akses dan referensi dari basis data Gen Bank NCBI yang digunakan untuk menentukan hubungan filogenetik terhadap jamur LBKURCC43.

\begin{tabular}{|lllll|}
\hline \multicolumn{1}{|c}{ Nama spesies } & $\begin{array}{c}\text { Kode Akses } \\
\text { Gen Bank }\end{array}$ & \multicolumn{1}{c|}{ Strain } & \multicolumn{1}{c|}{ Referensi } & $\begin{array}{c}\text { \% Identitas } \\
\text { hasil BLAST }\end{array}$ \\
\hline Kodamaea ohmeri & FJ215865.1 & - & & $99 \%$ \\
\hline Pichia ohmeri & AY168786.1 & ST-3 & Wang.,(2002) & $99 \%$ \\
\hline Hanseniaspora uvarum & DQ666349.1 & WZ1 & Hiringthugoda dkk.,(2006) & $97 \%$ \\
\hline Pichia guillermondi & FM178323.1 & - & Serena, C.,(2009) & $99 \%$ \\
\hline Kodamaea anthophila & HM156510.1 & CBS 8494 & Groenewald dkk.,(2011) & $96 \%$ \\
\hline Saccharomy cetales & EF060692.1 & LM378 & Mahdi dkk,.(2008 & $97 \%$ \\
\hline
\end{tabular}




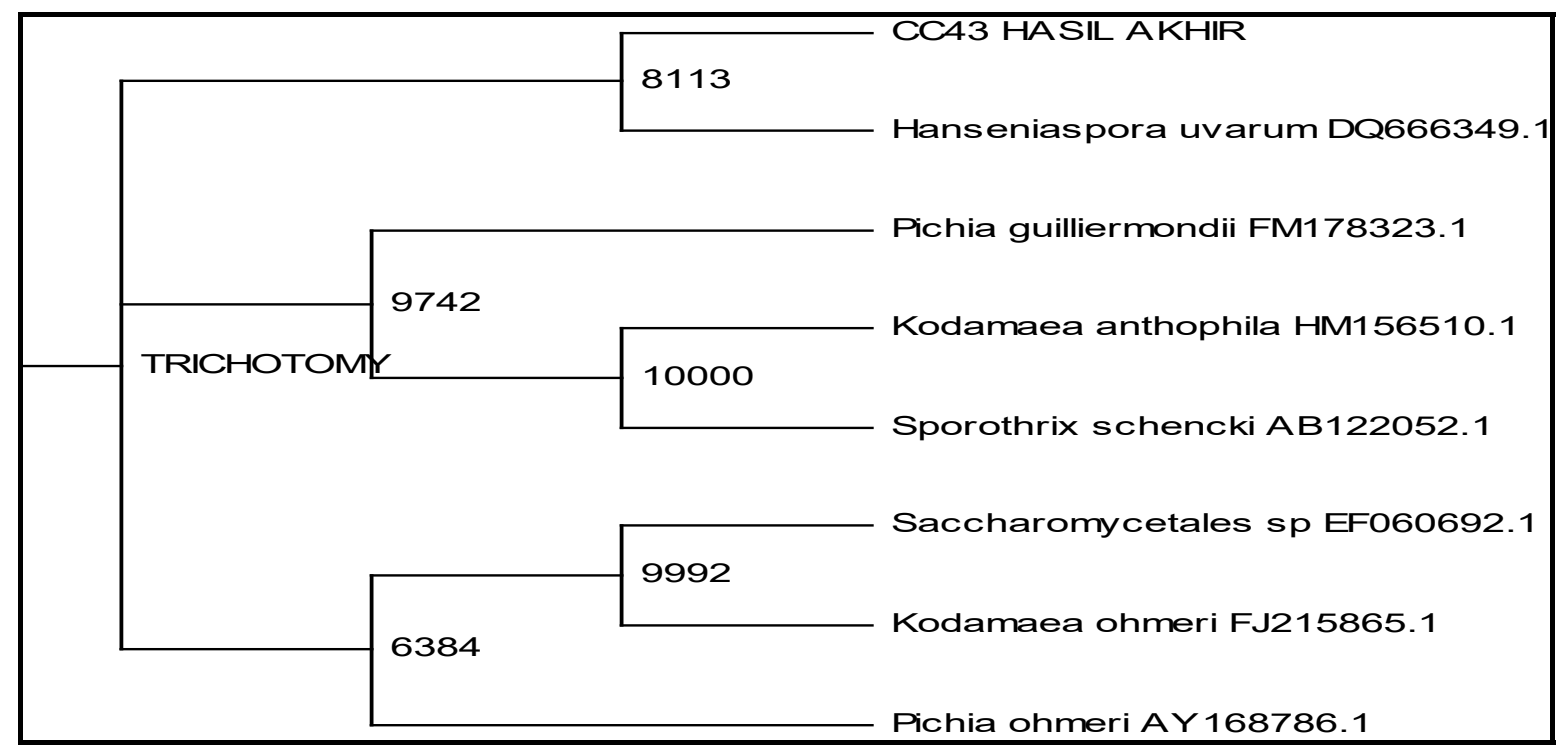

Gambar. 5 Dendogram Jamur LBKURCC43 dengan 7 galur terdekat berdasarkan sekuens daerah ITS-1 5,8S rDNA dan ITS-2.

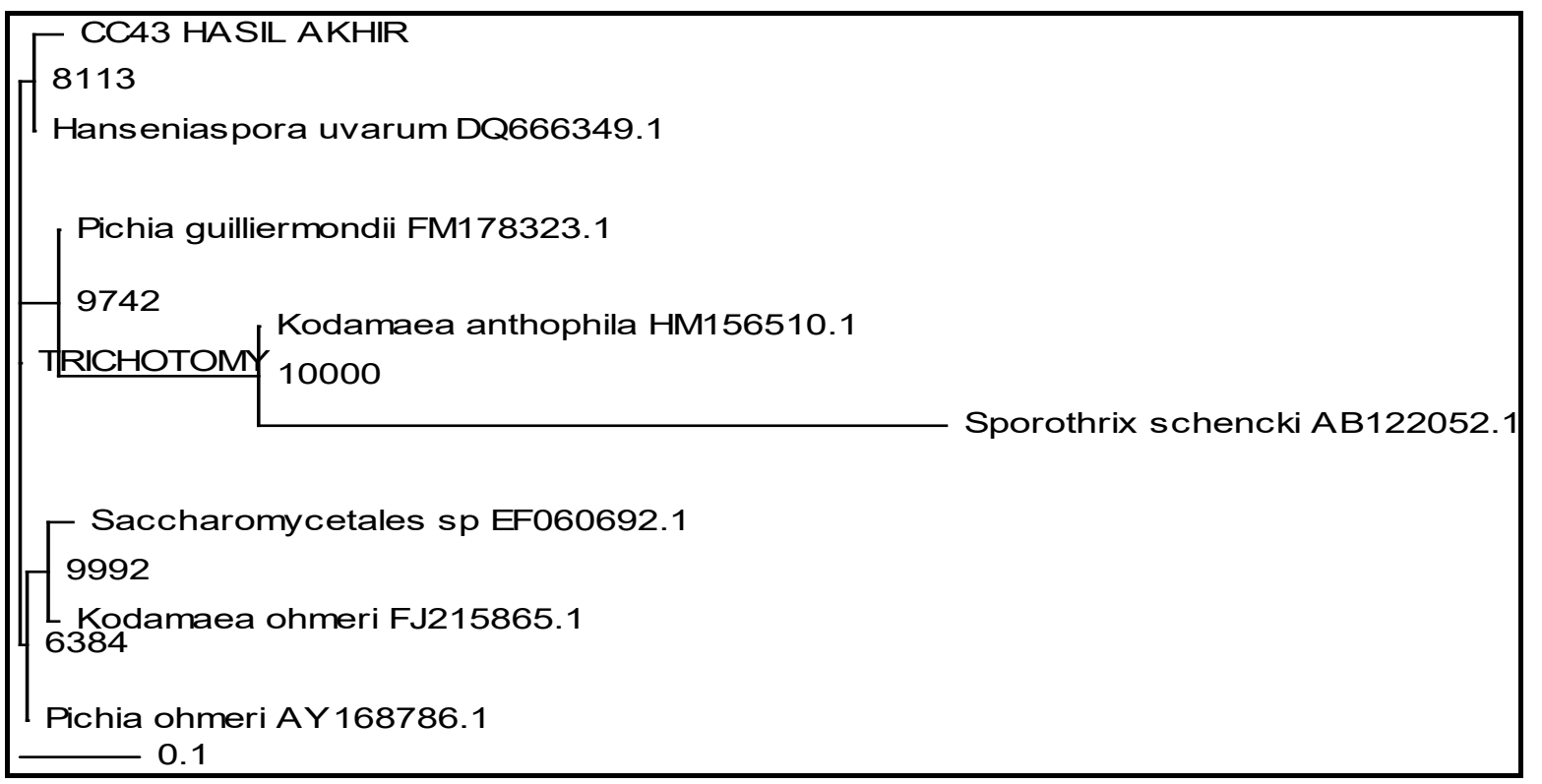

Gambar. 6 Hubungan Filogenetik LBKURCC43 dengan 6 galur terdekat, berdasarkan sekuens DNA ITS-1, 5,8S rDNA dan ITS-2.

Gambar 5 jamur LBKURCC43 dibandingkan dengan 7. Dari gambar digolongkan 2 subkluster yaitu:

1. Subkluster A mencakup 2 galur yaitu Hanseniaspora uvarum dan jamur LBKURCC43.

2. Subkluster B mencakup Kodamaea anthophila dan Sporothrix schencki.

3. Subkluster C mencakup 2 galur yaitu Saccharomyceteles $s p$ dan Kodamaea ohmeri.
Galur sub kluster A memiliki nenek moyang yang sama yaitu Haseniaspora uvarum dengan jamur LBKURCC43 sehingga boleh dikatakan memiliki hubungan kekerabatan yang lebih dekat dengan angka percabangan 8113 . Persentase hasil BLAST pada akses database GenBank menunjukkan homologi yang tinggi antara LBKURCC43 dengan 5 galur yang lainnya adalah berkisar 96\% sampai $99 \%$. Hal ini disebabkan oleh kromatogram sekuens DNA pada daerah ITS-1 dan ITS-2 pada jamur 
LBKURCC43 terbaca dengan menggunakan ITS5 (forward) maupun ITS4 (reverse). Sedangkan subkluster B merupakan kerabat dekat dari Kodamaea anthophila dan Sporohtrix schencki serta subkluster C merupakan kerabat dekat dari Saccharomyceteles sp dan Kodamaea ohmeri.

Penyejajaran jamur LBKURCC43 pada ke-5 galur dengan tes Bootstrap N-J tree dilakukan pengulangan 10000 kali ubtuk menguji kebenaran percabangan dan pohon filogenetika. Angka percabangan antara jamur LBKURCC43 dengan Haseniaspora uvarum sebesar 8113 pada subkluster B, artinya angka percabangannya berada diatas $50 \%$ (cukup tinggi. Jadi galur ini merupakan kerabat yang sangat dekat dan kedua sekuens DNA memiliki kesamaan namun strain berbeda.

Pada saat dilakukanya analisis BLAST menunjukkan kemiripan dengan kelompok khamir yaitu Hanseniaspora uvarum. Dimana jamur Hanseniaspora uvarum ini dikategorikan khamir dalam filum Ascomycota dan Basidiomycota. Beberapa khamir dilaporkan dapat menghambat patogen tanaman, khusunya patogen yang berada di dalam buah dan sayuran, serta beberapa produk komersial lainnya (Janisiewicz dan Korsten, 2002). Diketahui bahwa Hanseniaspora uvarum dapat digunakan untuk mengendalikan berbagai patogen penyebab pembusukan pada jeruk, buah pome, dan tomat (Chalutz \& Wilson, 1990).

\section{KESIMPULAN}

Dari hasil penelitian tentang analisis filogenetik dapat disimpulkan bahwa isolat DNA Fungi endofit LBKURCC43 memiliki 10.294 pb. Daerah rDNA yang mengandung ITS-1, 5,8S rDNA dan ITS-2 dari genom Fungi dapat diamplikasi dengan PCR menggunakan pasangan primer ITS4 dan ITS5. Hasil amplikasi pasangan primer ini diperoleh untuk Fungi LBKURCC43 adalah $455 \mathrm{pb}$.

Hasil persentasi dengan BLAST pada database GenBank untuk Fungi LBKURRCC41 menunjukkan bahwa sekuesn DNA diidentifikasikan sebagai Fungi Saccharomyces $s p$, yang memiliki kemiripan identifikasi $97 \%$. Pada saat hasil penjajaran dengan ke-7 galur spesies terdekat menunjukkan adanya hubungan filogenetik antar spesies Hanseniaspora uvarum, hal ini juga diperlihatkan oleh angka bootstrapping yang tinggi dengan 10000 kali pengulangan pada tiap percabangannya. Jadi dapat diprediksikan kemungkinan besar kerabat dekat pada masing-masing spesies.

\section{DAFTAR PUSTAKA}

Chalutz, E. and Wilson, C. L. 1990. Postharvest biocontrol of green and blue mold and sour rot of citrus by Debaryomyces hansenii. Plant Dis, 74: 134-137.

Ding, T., Jing, T., \& Zhou, J. 2010. Evaluation of antimicrobial activity of endophytic fungi from Camptotheca acuminata (Nyssaceae). Journal Genetics and Molecular Research 9 (4): 2104-2112

Druzhinina, I. S., Monika, K.Z., Ismail, A., Jaklitsch, W., Mullaw, T., Samuels, G.J., and Kubicek, C. P. 2012. Molecular phylogeny and species delimitation in the section Longibrachiatum of Trichoderma. Fungal Genetics and Biology 49 (2012) 358-368.

Fitriyah, D. 2013. Penentuan Media Optimum Produksi Senyawa Antimikrob Dari Jamur Endofit Tanaman Dahlia (Dahlia variabilis). Tesis. Jurusan Kimia FMIPA. Universitas Riau. Pekanbaru.

Huang, W.Y., Cai, Y.Z., Hyde, K.D., Corke, H., \& Sun, M. 2007. Endophytic fungi from Nerium oleander L (Apocynaceae) main constituents and antioxidant activity. World Journal of Microbiology and Biotechnology 23:9:1253-1263.

Janisewicz, W. J., Korsten, L. 2002. Biological control of postharvest diseases of fruits. Annual Review of Phytopathology. Vol. 40: 411-441.

Kumala, S., Agustina, E., \& Wahyudi, P. 2006. Uji aktivitas antimikrobial metabolit sekunder kapang endofit tanaman trengguli (Cassia fistula L). Jurnal Bahan Alam Indonesia ISSN. 2 (6):46-48.

Lorenita, M. 2013., Haryani, Y., Puspita, F., Trihartomo, D., Sikumbang, S., 2013. Screening of endophytic fungi from tubers of Dahlia variabilis. Journal of Agricultural Technology. 9(3): 565-570. 
Muslim. C. 2003. Biologi Molekular Sel. UNIB Press. Bengkulu.

Suryadi, A.E. 2007. Ekstraksi dan uji aktivitas antimikrob ekstrak umbi dahlia (Dahlia variabilis). Skripsi. Jurusan Kimia FMIPA. Universitas Riau. Pekanbaru.

Turk, F.M. 2006. Saponins versus plant fungal pathogens. Journal of Cell and Molecular Biology 5:13-17.

Weiese, J. Ohlendorf, B., Schmaljohann, R., Imhoff, J. S. Phylogenetic Identifacation of Fungi Isolated from the Marine Sponge Tethya aurantium and Identification of therr Secondary Metaboliter. Marine Drugs. 9: 516-585. Daya kecambah dan pertumbuhan Mucuna bracteata melalui pematahan dormansi dan pemberian zat pengatur tumbuh giberalin (GA3). Jurnal Online Agroteknologi. Vol.2, No.2; Hal 630-644.
Sutopo,.L. 2002. Teknologi Benih. Fakultas Pertanian. Universitas Brawijya. PT. Raja Grafindo Persada. Jakarta

Hartutiningsih dan Utami. 1999. Manipulasi KNO3 dalam upaya meningkatkan perkecambahan biji palem merah (Chrystotachys iakka Becc). Prosiding Seminar Nasional Konservasi Flora Nusantara. Balai Pengembangan Kebun Raya. Lembaga Ilmu Pengetahuan Indonesia. Bogor

Mugnisjah,.W.Q dan A. Setiawan. 1990. Produksi Benih. Bumi Aksara dan Pusat Antar Universitas. IPB. Bogor

Sulaiman,.F dan Gozali,.K 2004. Pengaruh Pematahan dormansi terhadap perkecambahan benih dan pertumbuhan bibit keranji (Dialium indum L.) Jurnal Tanaman Tropika Vol 7 (2); Hal 78-84. 